\title{
Compliance forces, domestic policy process, and international regulatory standards: Compliance with Basel III
}

\author{
Mehmet Kerem Coban ${ }^{1}$ \\ Pre-print version \\ Published in Business and Politics (2020) 22(1): 161-195
}

DOI: $10.1017 /$ bap.2019.3

\begin{abstract}
This article contributes to our understanding of how and why developing countries would comply with international banking regulatory standards, Basel standards. The article demonstrates the interplay between opportunity structures constituted by transnationalization of public policymaking and domestic institutional setting, and how forces of compliance resonate in the domestic politics of compliance. The empirical findings are based on Turkey's compliance with Basel standards. It relies on fieldwork that involves semi-structured qualitative interviews with senior regulators and bankers, which are complemented with analysis of secondary data. The article shows that a capable and willing regulator could capitalize on the top-down policymaking style which restricts the regulatee's access to international negotiations, and sets the terms at the domestic level. Direct access to international negotiations, resource asymmetry in favor of the regulator, and superior "negotiation knowledge" helped the regulator pacify a critical, sceptical regulatee, and drive the compliance process. The article also shows that the compliance process takes place at three stages: policy formulation at the international level, an "interpretation stage" in between the international and the domestic levels, and finally the domestic policy process.
\end{abstract}

Keywords: compliance, banking regulation, international regulatory standards, Basel III, developing countries

\footnotetext{
${ }^{1}$ Corresponding author: Mehmet Kerem Coban, Email: m.keremcoban@u.nus.edu.

Acknowledgments: Earlier versions of this paper were presented at the $3^{\text {rd }}$ International Conference on Public Policy (ICPP3) in Singapore in July 2017 and the $3^{\text {rd }}$ Interdisciplinary Worksop of Turkish Political Economy Society (TPES) at Bilkent University, Ankara in April 2018. I am grateful to the participants' comments and suggestions at these occasions. I am grateful to Ramkishen S Rajan, Kurtulus Gemici, Razeen Sally, David LeviFaur, Lucia Quaglia, Feng Qiushi, Michael Howlett, M Ramesh, Caner Bakir, Tolga Bolukbasi, Kathryn Lavelle, Federica Infantino, Iftikhar A. Lodhi, Yvonne Guo, Isha Dayal for their constructive suggestions and comments on the earlier versions of this paper. The author thanks the editors of the Special Issue and the journal as well as three anonymous referees. The author is grateful to interviewed regulators, central bankers, and bankers for their openness to the interview questions. The author gratefully acknowledges the PhD Academic Support Fund of the Lee Kuan Yew School of Public Policy, National University of Singapore, and organisational support of GLODEM, Koc University for hosting the author as a Research Associate.
} 


\section{Introduction}

Research suggests that compliance with international (regulatory) standards is driven by structural and cognitive drivers, with the prime "compliance forces" being: imposition (of the leading economies), ${ }^{2}$ peer competition, ${ }^{3}$ international harmonization, ${ }^{4}$ and learning. ${ }^{5}$ International standards may even be enforced through means of "hard law," sanctions or conditionalities, as well as through those of "soft law," including reputation concerns imposed upon domestic actors, peer review, or market pressure. ${ }^{6}$

While compliance forces justify whether or not a state adheres to international standards, domestic politics of compliance cannot be ignored. The policy processes at the international and the domestic levels are interdependent and intertwined leading to the creation of opportunity structures for domestic actors. ${ }^{7}$ Domestic actors can rely on transnationalization of public policymaking for their own advantage to shape domestic policies and institutions and promote and "export" them to the international level as standards. Or, they could benefit from such prevailing international standards, by "importing" them to redesign the domestic arena.

This article explores compliance of a "second mover" — a smaller economy that "imports" policies from the international level—with international regulatory standards. Specifically, the article examines Turkey's compliance with international banking regulatory standards, Basel III. Turkey's experience with compliance with Basel III is selected for three reasons. First,

\footnotetext{
${ }^{2}$ Drezner (2001); (2005); (2007).

${ }^{3}$ Simmons and Elkins (2004).

${ }^{4}$ Holzinger and Knill (2005).

${ }^{5}$ Dolowitz and Sharman (2009).

${ }^{6}$ Baccini and Urpelainen (2015); Bernauer and Koubi (2006); Brummer (2015); Chayes and Chayes (1993; 1995); Chey (2006); Ho (2002); Raustiala 2000; Simmons (2001); Slaughter (2004); Woods (2006).

7 Farrell and Newman (2014); (2016); see Cerny (2010), ch. 6 and Stone and Ladi (2015) on the transnationalization of public policymaking.

${ }^{8}$ Newman and Posner (2016).
} 
Turkey is a new member of the Basel Committee on Banking Supervision (BCBS), as the Committee expanded its membership in 2009 by including the remaining Group of Twenty (G20) countries (e.g., Indonesia, Mexico, Turkey), Singapore, and Hong Kong. A majority of new members are, overall, "fully compliant" with Basel III. ${ }^{9,10}$ In this light, the Turkish case is considered an illustrative case of a new BCBS member and a second mover complying with Basel III. Second, the Turkish case demonstrates that the regulators build on transnational sources to achieve full compliance with Basel III despite the banking sector's scepticism and critical stance. Third, the article is a response to the call for empirical studies in the Global South about how transnationalisation of policy processes could benefit domestic actors to alter domestic policies, institutions. ${ }^{11}$ The study helps shed light on exogenous forces for compliance, domestic policy processes, and the linkages between the two, which could be applied to other jurisdictions such as the new BCBS members' full compliance with Basel III and compliance with international regulatory standards in other policy sectors.

This article argues that three interlinked factors drove Turkey's compliance with Basel III. Firstly, the regulators' willingness to adopt Basel III, emanating from "compliance forces" of reputation, market pressure, and cognitive factors, pacified the critical and sceptical position of the banking sector. Secondly, an asymmetry between the regulator's "regulatory capacity" and the regulatee's "capture capacity" was in favor of the regulator, which defined the actors' relative position in the domestic policy process. Thirdly, and related to the second, the domestic institutional setting, an institutionalized "paternalistic," top-down domestic

\footnotetext{
${ }^{9}$ A jurisdiction is assessed "fully compliant" "[i]f all minimum provisions of the international framework [Basel framework] have been satisfied and if no material differences have been identified which would give rise to prudential concerns or provide a competitive advantage to internationally active banks" BCBS (2018), table 2 .

${ }^{10}$ For further details of the peer review process and review reports, see http://www.bis.org/bcbs/implementation/l2.htm, accessed on 1 November 2017.

${ }^{11}$ Farrell and Newman $(2014 ; 2016)$.
} 
policymaking style of the Turkish state ${ }^{12}$ restricted the opportunity structure created by transnationalization of public policymaking for mobilization of the regulatee in the domestic and the international levels.

While the article specifies which factors led to compliance, the compliance process itself is equally important. Compliance of second movers with international standards has been argued to occur in two stages. ${ }^{13}$ The first stage involves formation of a regulatory network and formulation of policies (or standards) at the international level. The second stage is at which domestic political bargain takes place, and which determines (non-)compliance. ${ }^{14}$ This article argues there is an intermediate stage between the international and the domestic policy processes. At this stage, domestic actors try to find answers to two interlinked questions: (A) Is adopting the international standards in their interest? (B) What are the costs and benefits of (non-)compliance? Finding answers to these questions refers to what we call the “interpretation process," a process of cost-benefit analysis whether or not (non-)compliance serves their interests. As preferences get crystallised at this stage, and these preferences influence interactions between the domestic actors. In short, (non-)compliance process takes place in three stages: policies are formulated initially at the international level, domestic actors make sense of the international standards, and finally, their interactions in the domestic policy process determines whether the state complies or not. As such, the article contributes to the classic two-stage framework of compliance, and presents a stage in between the global and the domestic policy processes.

\footnotetext{
${ }^{12}$ Bolukbasi and Ertugal (2018); see also Bakir (2015) on industrial policy.

${ }^{13}$ Mosley (2010); Newman and Posner (2016).

${ }^{14}$ Newman and Posner (2016).
} 
The article proceeds in four parts. The first part presents the analytical framework. The second part introduces the method. The third applies the framework to the Turkish case. The last section ends with concluding remarks and suggestions for future research.

\section{Compliance forces and the domestic policy process}

\section{Compliance forces and their sources}

Compliance has various sources. First, leading countries might impose their preferences on others, ${ }^{15}$ for example, through the closure of markets in developed countries to noncompliants. ${ }^{16}$ Competition between peers is the second force. ${ }^{17}$ Third, a collective effort to harmonize policies across borders can facilitate compliance. ${ }^{18}$ Finally, compliance can be driven by policy ideas travelling the world as policymakers seek to tackle similar policy problems by learning from peers' experience. ${ }^{19}$ Compliance may also occur due to the states' concerns about remaining a legitimate partner of a given network or international organization. Or, rule enforcement through means of "hard law" (e.g., conditionality) or "soft law" (e.g., damage on reputation, peer review), and market pressure can also drive states toward compliance. ${ }^{20}$

While compliance forces can drive a state toward (non-)compliance, transnationalization of public policymaking links tightly the domestic and international levels, which creates an opportunity structure (i.e., cooperation with transnational actors, access to international fora) for (non-)compliance. With access to international fora, the regulatee or the regulator can advance their positions at the domestic level for reasons such as (re)shaping the domestic

\footnotetext{
${ }^{15}$ Drezner (2001); (2005; 2007); Wood (2005).

${ }^{16}$ Chey (2007).

${ }^{17}$ Simmons and Elkins (2004).

${ }^{18}$ Holzinger and Knill (2005).

${ }^{19}$ Dolowitz and Sharman (2009); Holzinger and Knill (2005).

${ }^{20}$ Brummer (2015); Chayes and Chayes (1993; 1995); Chey (2006); Ho (2002); Jongen (2018); Raustiala (2000); Simmons (2001); Woods (2006).
} 
institutional context, gaining leverage in turf wars, defending or extending mandates, softening or fully averting implementation of international standards, or overcoming scepticism and critical position of other parties. ${ }^{21}$ To do so, compliance forces are necessary but insufficient for (non-)compliance. This is because compliance forces link the international and the domestic levels; ${ }^{22}$ and compliance forces are mediated at the domestic level, which produces the outcome of (non-)compliance.

\section{Domestic policy process and the politics of compliance}

Once compliance forces reach national borders, they trigger a compliance process in the domestic realm. For example, Mosley claims that "once rules are in place globally . . . compliance (or lack thereof) [in developing countries] will reflect bargaining outcomes among local private actors, regulatory officials and political actors." ${ }^{23}$ Newman and Posner also suggest such a two-stage compliance process. ${ }^{24}$ For authors, the initial stage is the formation of a policy network at the international level, whose policies are then exported to "policy taking" countries, which adapt themselves to the exported policy through a domestic policy process.

Two-stage frameworks assume that once compliance forces reach national borders, a bargain at the domestic level begins immediately. Yet we cannot ignore domestic actors' preferences, ${ }^{25}$ and the stage when preferences are constructed. This is because actors initially crystallize their respective preferences through an "interpretation process" before the (non)compliance process begins. The interpretation process involves domestic actors making sense of the international standards by finding answers to two interlinked questions: (A) Is adopting

\footnotetext{
${ }^{21}$ Farrell and Newman (2014; 2016); Newman and Posner (2018); Young (2014); Xi (2016).

${ }^{22}$ Putnam (1988); see also Quaglia (2019); Quaglia and Spendzharova (2017).

${ }^{23}$ Mosley (2010), 732.

${ }^{24}$ Newman and Posner (2016).

${ }^{25}$ Moravcsik (1997).
} 
the international standards in their interest? (B) What are the costs and benefits of (non)compliance?

In the case of compliance with international banking regulatory standards, the banking sector assesses the standards in line with the costs and benefits of compliance. Demirguc-Kunt, Laeven, and Levine find that restrictive regulations are likely to increase the costs of financial intermediation. ${ }^{26}$ Pasiouras, Tanna, and Zopounidis argue that the effect of compliance with standards on bank performance is mixed: an analysis of the three pillars of the previous version of the Basel framework (Basel II) reveals that cost efficiency rises when regulations boost market discipline, but profit efficiency declines when regulations impose stricter capital adequacy ratios. ${ }^{27}$ On the other hand, Ayadi et al. maintain that banks in developing countries may observe a positive effect on input efficiency (relatively cheaper cost of capital— deposits, debt, etc.). ${ }^{28}$ Yet the banking sector is known to mobilize against restrictive regulations at either international or domestic levels. Thus, it is legitimate to expect them to mobilize against restrictive regulatory standards.

Once we examine why regulators would comply or not, unless they are "captured" by the local banking sector against compliance and resist compliance for several reasons including fear of losing monopoly on domestic regulatory policymaking or high compliance costs, regulators are expected to adopt and enforce international regulatory standards because compliance can serve various objectives. For example, regulators can gain leverage in the domestic realm by adopting and enforcing international standards. For instance, $\mathrm{Xi}$ argues that the Chinese central bank uses compliance with Basel III to gain leverage against the banking

\footnotetext{
${ }^{26}$ Demirguc-Kunt, Laeven, and Levine (2011).

${ }^{27}$ Pasiouras, Tanna, and Zopounidis (2009).

${ }^{28}$ Ayadi et al. (2016), 16.
} 
regulatory agency and the Chinese banks to strengthen its relative position vis-à-vis the two actors in adoption and implementation of international standards. ${ }^{29}$ Or, the regulator might aim to represent itself as legitimate and skilled with compliance to disguise weaknesses in organizational capacity. ${ }^{30}$ Alternatively, the regulator can use compliance to build organizational capacity, which in turn helps the regulator maintain legitimacy and gain leverage vis-à-vis the regulatee or other domestic actors. Additionally, by following international policies, regulators can address a policy dilemma: either follow domestic priorities or cooperate with peers. ${ }^{31}$ Also, (over)compliance could result from reputation concerns. For example, Knaack asserts that China's (over)compliance with Basel III stems from the regulators' concern to signal a good quality regulatory framework. ${ }^{32}$

Following crystallization of preferences of regulators and the regulatee in light of the preference formation-guiding motives discussed above, the third stage is where domestic actors engage in a bargain whose terms are dictated by actors' power resources (e.g., access to information, skilled human resources, ${ }^{33}$ political skills, etc.) and the domestic institutional context (i.e., the policymaking structure) that shape the opportunity structure in the domestic realm. As for actors' resources, drawing from the policy capacity literature, resources of an actor have three dimensions: analytical, political, and operational. ${ }^{34}$ Analytical capacity refers to access to data, skills to process that data, and ability to apply the knowledge produced out of data processing in the design and/or implementation of a given policy. Political capacity involves learning and understanding others' interests to mobilize others to

\footnotetext{
${ }^{29} \mathrm{Xi}$ (2016).

${ }^{30}$ Boot and Thakor (1993).

${ }^{31}$ Kapstein (1989); (1992); (1994); Oatley and Nabors (1998); Singer (2007).

${ }^{32}$ Knaack (2017).

${ }^{33}$ The article uses the notions of "human resources," "human resource base" when it refers to workforce of an organization. It uses "employees" when it refers to individual workers.

${ }^{34} \mathrm{Wu}$, Ramesh, and Howlett (2015); Wu, Howlett, and Ramesh (2018).
} 
achieve one's preferred outcomes. Finally, operational capacity refers to human and financial resources required for the functioning of an organization.

Acquiring analytical skills, attracting skilled labor, having political skills, and access to data and information define the "regulatory capacity" of domestic regulators. Relying on these resources, regulators can perform the required policy functions. ${ }^{35}$

In the case of the regulatee, acquisition of analytical, political, and operational resources determine the regulatee's "capture capacity." The banking sector is well-known for its skilful, influential lobbying either at domestic or international levels or at both. ${ }^{36}$ Mobilization requires a solid understanding of the costs and benefits of compliance in a technical and complex policy sector. Thus, acquisition of analytical, operational, and political resources, and skills are essential for the regulatee to initially make sense of the regulations, and then, if it could, influence the policy process in line with its interests.

Moreover, the institutional context and the policymaking style of regulators set the rules of the domestic policy process as well as the opportunity structures in the domestic level. A "pluralist" institutional context and an inclusive policymaking style enable participation of non-state actors in the policy process. However, not all actors might have equal access to the policy process. ${ }^{37}$ In domestic politics of compliance, the participation of the regulatee in the domestic policy process is subject to the responsiveness of regulators to regulatee's demands. ${ }^{38}$ Thus, if regulators have the will and/or capacity to restrict the regulatee's access

\footnotetext{
${ }^{35}$ Maggetti and Gilardi (2014), 1297; see also Bach and Newman (2007); Chayes and Chayes (1993); García and Aspinwall (2017); Marcoux and Urpelainen (2012); Murinde (2012); VanDeveer and Dabelko (2001).

${ }^{36}$ Baker (2010); Howarth and Quaglia (2013); James (2016); Lall (2012); (2015); Underhill and Zhang (2008); Quaglia (2007); Young (2013); (2014).

${ }^{37}$ Lindblom (1968); Lowi (1969).

${ }^{38}$ Woll (2007).
} 
to the policy process, the regulators can restrict the regulatee's access in the domestic policy process and even to the global policymaking process by limiting their mobilization through the opportunity structure the transnationalization of the policy process creates.

Finally, one may wonder whether elected politicians have a role in the domestic policy process. For example, politicians could be both a "principal" delegating compliance task to regulators, but then become an ally of the regulatee against the regulators at the adoption stage. ${ }^{39}$ Such important roles of the politicians are more impactful in jurisdictions with multiple levels of policymaking, such as the United States or the European Union. For example, the Congress in the United States can dictate the terms of an international agreement. ${ }^{40}$ In contrast, in jurisdictions with fewer levels of policymaking, such as Turkey and other unitary states, the policymaking process grants a limited role to political actors. In these jurisdictions, political actors can be more influential at an earlier stage even before compliance forces are triggered at the international level. As the "principal," politicians can choose whether or not to commit the jurisdiction to compliance at international summits. Assuming that the jurisdiction is committed to compliance, design and implementation of international regulatory standards become a technical issue. It is true that the process can be politicized. But, it requires political salience to cross a threshold forcing politicians to intervene. Until the issue crosses that threshold, the process is technical and is subject to a bargain between the regulator and the regulatee.

\footnotetext{
${ }^{39}$ Quaglia (2019).

${ }^{40}$ Lavelle (2013; 2019); Oatley and Nabors (1998); Rosenbluth and Schaap (2003).
} 
Figure 1: Compliance Forces and the Domestic Policy Process

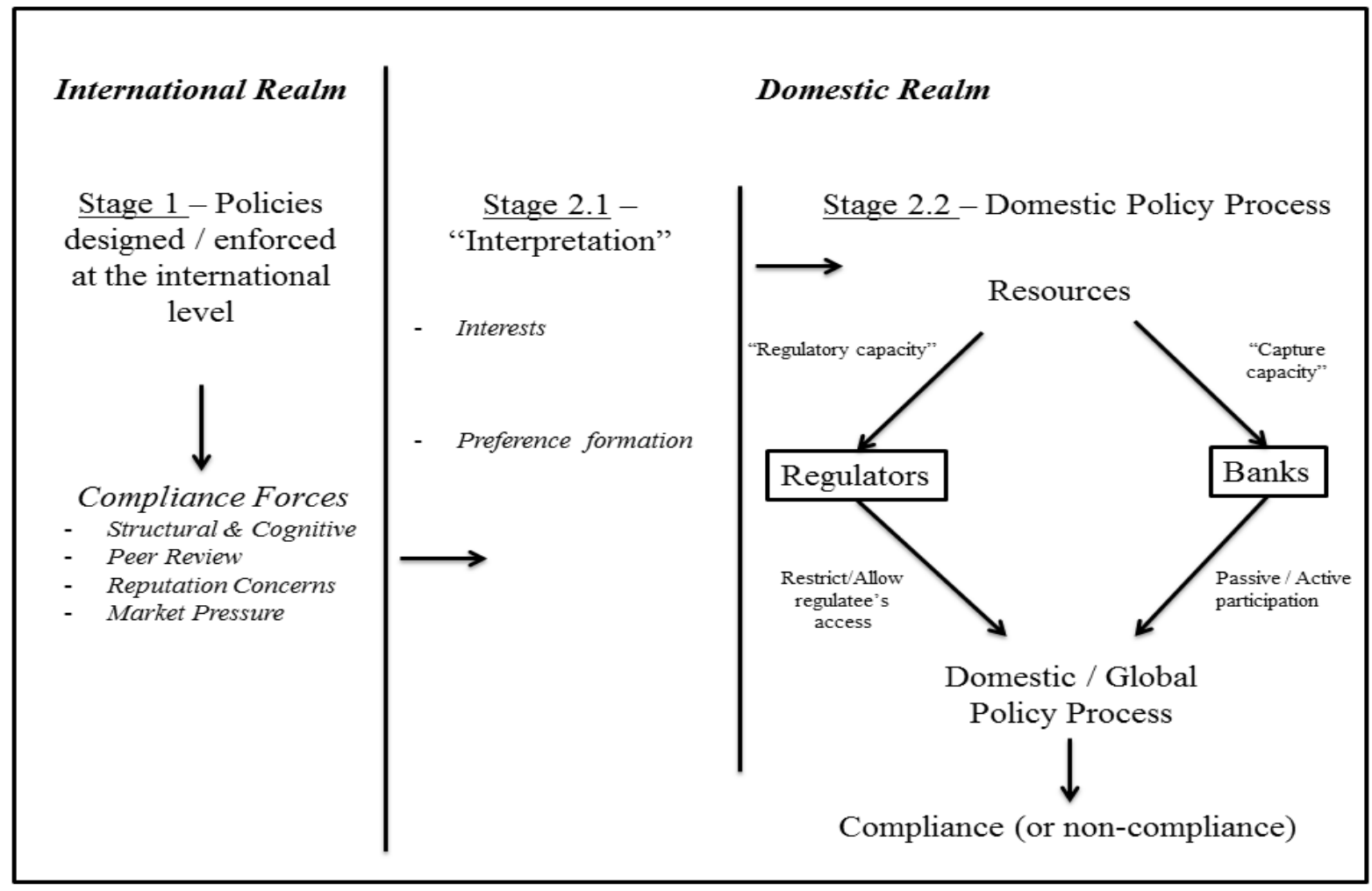

In short, figure 1 depicts the stages of (non-)compliance. The first stage is at which policies are formulated and enforced at the international level. The domestic policy process begins afterwards. The first stage in the domestic realm is between the international and the domestic policy process, at what is called the interpretation stage. At this stage, domestic actors crystallize their preferences regarding (non-)compliance. Finally, the domestic actors engage in a domestic policy process that is regulated by their respective resources, and the interplay between the domestic institutional setting and the opportunity structure constituted by interdependence in terms of access to international fora.

\section{Method}

This article adopted an exploratory qualitative research design. The empirics are based on fieldwork that took place during the first quarter of 2016. It involved nineteen in-depth, semistructured elite interviews with individual or groups of senior officials in the Banking Regulation and Supervision Agency ("BDDK" in Turkish, hereafter BRSA) and commercial 
banks given the centrality of commercial banks in the Turkish banking sector in terms of total assets as table 1 below indicates (see appendix 1 for more information about the interview data).

Turkey is a bank-based system. More than 80 percent of financial assets are held in the banking sector, ${ }^{41}$ which indicates that compliance with Basel III has serious financial ramifications for the Turkish banking sector. Table 1 shows that the number of banks declined after the local economic and banking crises in 2000 and 2001. Since then, the number of foreign-owned banks has risen, while the number of privately-owned banks has declined. Foreign-owned commercial banks are subsidiaries, and there are foreign-owned investment banks that are branches of foreign investment banks. Currently, there are fifty-two banks in Turkey.

Table 1: Number of Banks

\begin{tabular}{|c|c|c|c|c|c|c|c|c|c|c|c|}
\hline Type / Year & 2000 & 2005 & 2010 & 2011 & 2012 & 2013 & 2014 & 2015 & 2016 & 2017 & March 2018 \\
\hline Commercial Banks & 61 & 34 & 32 & 31 & 32 & 33 & 33 & 33 & 34 & 34 & 34 \\
\hline State-owned & 4 & 3 & 3 & 3 & 3 & 3 & 3 & 3 & 3 & 3 & 3 \\
\hline Foreign-owned & 18 & 13 & 17 & 16 & 16 & 17 & 19 & 21 & 21 & 21 & 21 \\
\hline Privately-owned & 28 & 17 & 11 & 11 & 12 & 12 & 10 & 8 & 9 & 9 & 9 \\
\hline SDIF & 11 & 1 & 1 & 1 & 1 & 1 & 1 & 1 & 1 & 1 & 1 \\
\hline Development and Investment Banks & 18 & 13 & 13 & 13 & 13 & 13 & 13 & 13 & 13 & 13 & 13 \\
\hline Participation Banks & - & 4 & 4 & 4 & 4 & 4 & 4 & 5 & 5 & 5 & 5 \\
\hline Total & 79 & 51 & 49 & 48 & 49 & 50 & 50 & 51 & 52 & 52 & 52 \\
\hline
\end{tabular}

Source: Banks' Association of Turkey (2016a; 2016b; 2018).

Note: "SDIF" is the Savings and Deposit Insurance Fund; "Participation Banks" are Islamic banks; Banks are ranked by total assets in U.S. dollars as of December each year except 2018.

Table 2 illustrates the top fifteen and top five banks by total assets by ownership. The Turkish banking sector is dominated by privately-owned banks and state-owned banks. This means that although the number of foreign banks has risen since 2000, their presence did not lead to a higher level of penetration in the form of total assets and market share. Further, table 2

\footnotetext{
${ }^{41}$ CBRT (2013), Chart III.1.
} 
indicates that commercial banks are situated at the centre of the Turkish banking sector by total assets.

Table 2: Number of Banks, Top 15 and Top 5 by Total Assets

\begin{tabular}{|c|c|c|c|c|c|c|c|c|c|c|c|}
\hline Year & 2000 & 2005 & 2010 & 2011 & 2012 & 2013 & 2014 & 2015 & 2016 & 2017 & September 2018 \\
\hline \multicolumn{12}{|l|}{ Top 15} \\
\hline Commercial Banks & 14 & 14 & 14 & 13 & 13 & 14 & 14 & 14 & 13 & 13 & 13 \\
\hline State-owned & 4 & 3 & 3 & 3 & 3 & 3 & 3 & 3 & 3 & 3 & 3 \\
\hline Foreign-owned & 1 & 2 & 5 & 4 & 4 & 5 & 5 & 5 & 6 & 5 & 6 \\
\hline Privately-owned & 8 & 9 & 6 & 6 & 6 & 6 & 6 & 6 & 4 & 5 & 4 \\
\hline SDIF & 1 & - & - & - & - & - & - & - & - & - & - \\
\hline Development and Investment Banks & 1 & 1 & 1 & 2 & 2 & 1 & 1 & 1 & 2 & 2 & 2 \\
\hline Participation Banks & - & - & - & - & - & - & - & - & - & - & - \\
\hline \multicolumn{12}{|l|}{ Top 5} \\
\hline Commercial Banks & 5 & 5 & 5 & 5 & 5 & 5 & 5 & 5 & 5 & 5 & 5 \\
\hline State-owned & 2 & 2 & 1 & 2 & 1 & 1 & 1 & 1 & 1 & 2 & 1 \\
\hline Foreign-owned & - & - & - & - & - & - & - & 1 & 1 & 1 & 1 \\
\hline Privately-owned & 3 & 3 & 4 & 3 & 4 & 4 & 4 & 3 & 3 & 2 & 3 \\
\hline SDIF & - & - & - & - & - & - & - & - & - & - & - \\
\hline Development and Investment Banks & - & - & - & - & - & - & - & - & - & - & - \\
\hline Participation Banks & - & - & - & - & - & - & - & - & - & - & - \\
\hline
\end{tabular}

Source: Banks' Association of Turkey, author's compilation.

Note: "SDIF" is the Savings and Deposit Insurance Fund; "Participation Banks" are Islamic banks; Banks are ranked by total assets in US dollars as of December each year except 2018.

Against this background, the study conducted nine interviews with senior bankers working in the Risk Management or Internal Systems and Compliance departments in nine banks and one with senior officials in the Banks' Association of Turkey (hereafter BAoT). These departments were targeted because they steer compliance with international regulatory standards. Banks were targeted according to total assets. ${ }^{42}$ They were among the top fifteen banks by total assets as of June 2015. The initial list of targeted banks included three stateowned banks, but two of them were omitted because the largest state-owned bank, Ziraat Bank, was considered representative of the other two remaining state-owned banks, which were ranked sixth and seventh. Garanti Bank, a foreign-owned bank ranked third, was also targeted but had to be omitted because the targeted senior banker did not have an available slot for an interview and did not refer a colleague for a replacement. Consequently, the sample

\footnotetext{
42 See appendix 1 for their rank by total assets. Before the fieldwork, the data was accessible at https://www.tbb.org.tr/en/banks-and-banking-sector-information/statistical-reports/june--2015---turkish-banks--ranked-by-total-assets---usd/1077, accessed on 10 September 2015. The new web link is as follows, https://www.tbb.org.tr/en/banks-and-banking-sector-information/statistical-reports/20, accessed on 27 January 2019.
} 
included nine banks: a state-owned bank (Ziraat Bank), three privately-owned banks (T. Is Bank, Yapi Kredi Bank, and Akbank), and five foreign-owned banks (ING, TEB, Denizbank, Finansbank, and HSBC). The sample covered a wide range of banks by including the largest state-owned, foreign-owned, and privately-owned banks by total assets, ${ }^{43}$ as well as those with a somewhat smaller market share. As such, the sample is representative of the Turkish banking sector.

Bankers were selected according to seniority and position in the department. Two interviews were conducted with two senior bankers at T. Is Bank. This is because one of the bankers was the former head of the BAoT while the other was working in the Risk Management department. Five out of ten interviews (i.e., at Ziraat Bank, Yapi Kredi Bank, Akbank, Finansbank, and BAoT) were group interviews because the targeted interviewees invited their colleagues in the department to the interview. Although this was not intended when the researcher first contacted the interviewee, the interviewee suggested having his/her colleagues present for an in-depth discussion. The researcher agreed with the expectation of gathering quality interview data with the contribution of more senior officials working in the same department. During these interviews, the research did not observe conflicting statements. Each official's statement rather complemented that of the other colleague(s) and enriched the interview content.

In the public sector, the researcher interviewed eight senior regulators at the BRSA, using both purposive and snowball sampling. The interviewees were targeted according to seniority as well as participation in the BCBS meetings and/or in the design and implementation of the Basel framework. As for purposive sampling, the researcher contacted a senior regulator (R3).

\footnotetext{
${ }^{43}$ See ranking by total assets by ownership structure, available at https://www.tbb.org.tr/en/banks-and-bankingsector-information/statistical-reports/20, accessed on 27 January 2019.
} 
Snowball sampling was then used upon referrals. R3 connected the researcher with another senior regulator (R4). R4 helped the researcher contact a former senior regulator (R2) who connected the researcher to another former senior regulator (R1). R4 also assisted the researcher in contacting current senior regulators (R5, R6, R7, and R8).

It should be noted that this study did not include central bankers in the sample. Indeed, as part of a project on the political economy of banking regulation in Turkey in the post-Global Financial Crisis (GFC) period, the fieldwork included interviews with senior central bankers on compliance with Basel III. ${ }^{44}$ Although the researcher was aware that the BRSA is the sole authority in Turkey to steer compliance and enforcement of the Basel standards, two interviews with senior central bankers were conducted to cross-check if the Central Bank of Republic of Turkey (CBRT) played a significant role in Turkey's compliance with Basel III. The central bankers stated that they participated in working groups that specialized in liquidity, sovereign risk, and macroprudential supervision, but emphasised that the BRSA led the process. The interviews also revealed that the CBRT supported compliance with exactly the same reasons the regulators stated. Consequently, the interviews were interpreted as the politics of compliance took place between the regulatee and the regulator. Therefore, the researcher chose not to include central bankers' views in this analysis.

Besides interviews, secondary data complemented the data collection process. Media reports, the BCBS Basel III progress reports, the BRSA's annual reports and surveys on Basel framework implementation, and the BAoT's reports and briefs on the Basel framework were analyzed for a triangulation of interview data.

\footnotetext{
44 Interview, three senior officials at CBRT, Ankara, 12 January 2016; Interview, senior official at CBRT, Ankara, 28 January 2016. Interviewed central bankers were working in the Banking and Financial Institutions Department and Communications and Foreign Relations Department, which steer relations with domestic macroeconomic bureaucracies, international organizations and financial organizations (Bakir and Coban (2018)).
} 
As for data analysis, the interviews were first transcribed in Turkish, and were later translated by the researcher into English. The transcripts and written data were analyzed on NVivo software to find out emerging themes to reach analytical and theoretical saturation.

\section{Compliance forces, domestic policy process, and compliance with Basel III}

\section{Background: Turkey and the Basel Framework}

The literature on the relationship between the BCBS and Turkey only discusses the potential impact of compliance for the Turkish banking sector and small-and-medium-sized enterprises $(\mathrm{SMEs})^{45}$ while it ignores the conditions or process that led to compliance. Külahi, Türyaki, and Y1lmaz document that the Treasury — the banking regulator before institutional reforms in the early 2000s - incorporated Basel I standards into the Turkish regulatory framework in the early 1990s, which indicates that the "formal" exchanges with the BCBS began at least in the 1990s. ${ }^{46}$ After the local economic and banking crises in 2000-2001, the country restructured the banking sector and the regulatory governance structure in the country, which was accompanied by incorporation of Basel II in the Banking Law No. 5411 in $2006{ }^{47,48}$

The law imposed an 8 percent capital adequacy ratio, addressed deficiencies in corporate governance and accountability, and more importantly, aimed to make the banking sector internalize the logic of risk management and build a robust internal auditing system. ${ }^{49}$ The primary missing dimension in adherence to Basel II was the introduction of internal-based risk assessment models, which slowed full compliance with Basel II. This was partly related

\footnotetext{
${ }^{45}$ Bayraktar (2015); Hassan, Unsal, and Tamer (2016); Karacal, Can, and Arslan (2013).

${ }^{46}$ Külahi, Türyaki, and Yılmaz (2013).

${ }^{47}$ See Bakir (2009) for a discussion about institutional reforms in the regulatory governance structure after the local economic and banking crises in 2000-2001.

${ }^{48}$ Banking Law No 5411, published in the Official Gazette on 19 November 2005.

${ }^{49}$ Külahi, Türyaki, and Y1lmaz (2013), 190-91.
} 
to a lack of quality human resource base both in the BRSA and the Turkish banking sector, and deficiencies in the technological infrastructure. ${ }^{50}$

In the meantime, Turkey and several other jurisdictions became members of the BCBS in 2009. Following the formulation and enforcement of Basel III, the peer review of the BCBS, which was established in the post-GFC period, evaluated Turkey as fully compliant with the framework in 2016. ${ }^{51}$ The Thirteenth Progress Report of the BCBS also reports that additional measures were introduced to bring Turkey's regulatory framework in line with Basel III in 2015 and $2016 .{ }^{52}$ To be assessed as "fully compliant," the BRSA passed several regulations before and particularly during Turkey's peer review process. These regulations involved the capital surcharge on domestic systemically important banks (D-SIBs), the redefinition of capital, and the leverage ratio. Here, one may consider the difference between Turkey's compliance with Basel II and Basel III. As the analysis below shows, compliance forces originating from Turkey's membership to the BCBS did not exist before 2009. Further, compliance forces then were reinforced by the build-up of skilled human resource base in the BRSA, the regulator's willingness, and a restrictive policymaking structure.

\section{Stage 1: The BCBS, Basel III, and compliance forces}

The BCBS, which emerged as an influential forum for international policy coordination in banking regulation since its foundation, was formed by the Group of Ten (G10) central bank governors in mid-1970s. ${ }^{53}$ It was founded on the basis of "soft law," whose primary objective

\footnotetext{
${ }^{50}$ BDDK (2013); see also Bakir and Öniş (2010), 101.

${ }^{51}$ The RCAP report is available at http://www.bis.org/bcbs/publ/d359.pdf and https://www.bis.org/bcbs/publ/d360.pdf, accessed on 8 January 2018.

${ }^{52}$ See the Thirteenth Progress Report on the Adoption of the Basel Regulatory Framework, http://www.bis.org/bcbs/publ/d418.htm, accessed on 8 January 2018.

${ }^{53}$ Goodhart (2011).
} 
was information exchange and policy coordination without a formal legal status with sanctioning powers. ${ }^{54}$

The GFC constituted a critical juncture for the BCBS. First of all, its membership expanded with the inclusion of the remaining countries of G20 and two financial centres, Singapore and Hong Kong. In the aftermath of the GFC, G20 countries committed to improving the quality of regulatory standards and coordinating policies so as to ensure a level playing field and prevent fragmentation and regulatory arbitrage in the international financial system; ${ }^{55}$ which points to an international effort to harmonize local regulatory frameworks in the post-GFC period.

In the meantime, the BCBS updated Basel II. Basel III reflects a macroprudential approach, which emerged in the post-GFC period. ${ }^{56}$ Basel III re-defined capital, adding more layers of prudential regulations: capital surcharge on domestic and global systemically important banks, liquidity coverage ratio, counter-cyclical capital buffer, net stable funding ratio, among many others. Moreover, the BCBS launched a peer review system called Regulatory Consistency Assessment Programme (RCAP). ${ }^{57}$ Previously, peer reviews of regulatory consistency were not part of the enforcement capacity of the BCBS. Although the "soft law"orientation of the BCBS still remains, the results of the peer review process can put pressure on the credibility of local regulatory frameworks, as RCAP disseminates information about regulatory consistency and the quality of the local framework. Signalling a lower quality can trigger peer pressure in regards to a member's willingness to be part of collective action towards policy harmonization. Besides, market pressure can be an important force particularly

\footnotetext{
${ }^{54}$ Abbott and Snidal (2000); Avgouleas (2012); Brummer (2015); Goldbach (2015a); (2015b); Goodhart (2011).

${ }^{55}$ G20 (2009).

${ }^{56}$ Baker (2013); Kobrak and Troege (2015).

${ }^{57}$ Goldbach (2015a; 2015b).
} 
for smaller markets, not only in the form of the closure of foreign markets, but also rising borrowing costs in the banking sector. Under these conditions, compliance forces involve peer pressure, reputation concerns, market pressure, and collective efforts to harmonize policies, which also can activate socialization channels in an international organization setting.

\section{Stage 2.1: Interpretation}

We have discussed above that once compliance forces are triggered with enforcement of policies at the international level, the (non-)compliance process does not begin immediately at the domestic level. Here, the stage before the domestic political bargain begins, an earlier stage relates to the interpretation stage. At this stage, domestic actors assess whether or not compliance is in their interest and the costs and benefits of (non-)compliance. During this process, compliance forces assist domestic actors as they are making sense of "signals" broadcasted through compliance forces, and rationalize (non-)compliance according to the "signals" of compliance forces.

In the case of Turkey's compliance with Basel III, we can observe the aforementioned compliance forces, in particular learning, socialization, competition with peers, and “coercion.” To begin with structural, cognitive forces, a regulator notes

[First] [as a member of the BCBS] you learn instruments, tools, and how they are designed. [Second], when your peers such as Mexico and China are assessed as compliant in RCAP, you cannot be non-compliant or materially-compliant... Your promises as a member of the club require you to comply. Although you join the club voluntarily, you have to adopt the standards to whose formulation you contribute [in 
the BCBS]... [Further] socialisation is important because working with others [in the 'kitchen'] help you learn about others' experiences." 58

Another regulator notes "coercion," which also has a dimension of competition with peers: "membership is not voluntary. When the remaining members of G20 were becoming a member of the BCBS, it would have been very difficult to remain out of the 'club' when others were joining it." 59

Moreover, market pressure can penalize non-compliance. Both regulators and bankers are concerned with costs of non-compliance, with an emphasis on attracting foreign capital with lower borrowing costs. For example, representing both bankers' and regulators' concerns, a banker notes that "we have to be compliant with the framework for two reasons. First, we need to attract foreign capital. Second, international investors know the differences between being fully compliant, materially compliant and non-compliant." ${ }^{60}$ The statement notes a low savings rate in Turkey, an unfavorable macroeconomic structure reinforcing concerns about non-compliance; and which has to be compensated with "importing" foreign savings. ${ }^{61}$

While agreeing on the potential influence on importing foreign savings, regulators also are concerned with their reputation to remain an open economy as well as a legitimate partner in the BCBS. A senior regulator mentions that "if you want to remain an open economy and be part of the international system and attract capital, you must adopt the framework." ${ }^{, 62}$ Another regulator underlines that "when you join there [the BCBS], you promise to comply with the rules, you and your peers in the Committee design [the framework] together. If you do not

\footnotetext{
${ }^{58}$ Interview, R5, BRSA, Ankara, 21 January 2016.

${ }^{59}$ Interview, R8, BRSA, Istanbul, 11 February 2016.

${ }^{60}$ Interview, B3, T. Is Bank, Istanbul, 1 March 2016.

${ }^{61}$ IMF (2017: 26) reports that one of the most fundamental risks for financial instability in Turkey is structural low private savings rate which reached a historically low level around 10 percent of GDP by the end of 2015.

${ }^{62}$ Interview, R5, BRSA, Ankara, 21 January 2016.
} 
follow the very same rules, your status as a legitimate partner would be questioned. Although the BCBS cannot sanction you, you still would not prefer non-compliance because it hurts your reputation.",63

Finally, peer review plays a crucial role next to the other factors. Peer review is closely linked to learning and socialization channels, while its outcome can activate "coercion" and market pressure forces in the case of non-compliance. The RCAP peer review of Turkey began in the fourth quarter of 2015, and ended by the end of the first quarter of 2016, and assessed the country fully compliant with Basel III. A regulator notes that "during the visits, we discuss standards and country-specific regulations to find out good practices, and how to converge on the agreed framework. During the process, policy learning undoubtedly happens. ${ }^{\prime 64}$ What is more, both regulators and bankers agree on the fact that the peer review transmits information about the quality of local regulatory framework as put by a regulator "if you do not follow the standards, the RCAP process demonstrates inconsistencies. Both the banking sector and our peers know what red, yellow, or green mean. If you get a 'red,' it will raise questions about your commitment, credibility to enforce the framework." 65

The statements indicate how bankers and regulators interpret compliance forces, which serves to make sense of what might happen if they comply or not. This in turn translates into the rationalization of (non-)compliance given the "signals" transmitted by compliance forces.

\footnotetext{
${ }^{63}$ Interview, R6, BRSA, Ankara, 22 January 2016.

${ }^{64}$ Interview, R6, BRSA, Ankara, 22 January 2016.

${ }^{65}$ Interview, R8, BRSA, Istanbul, 11 February 2016. The interviewee refers to colours that represent the level of compliance. Green means "full compliance", yellow refers to "largely compliant," red means "materially noncompliant," purple refers to "non-compliant"; see https://www.bis.org/bcbs/implementation/rcap_jurisdictional.htm, accessed on 11 January 2018.
} 
While compliance forces help actors interpret the credibility of "sanctions" in the case of noncompliance, they, in the meantime, interpret the relative position of the country within the international financial system, which define the "policy space" of a state following a globally enforced policy with respect to its capacity to protest or avoid regulations, or at least bypassing through amendments at the domestic level while appearing compliant on paper. ${ }^{66}$ Here, one could understand that both Turkish bankers and regulators share similar concerns in regard to compliance. However, the Turkish banking sector still has legitimate concerns. The bankers are both critical and sceptical of how the framework is adopted and enforced, and about the future costs of compliance, although they agree on costs of non-compliance. Another banker mentions that "the shareholder imposes a target return-on-equity at the beginning of the year. The regulator forces me to build buffers with more capital put aside, while the local market is dominated by the domestically-owned banks. How can I achieve the target in this context?"

Bankers are also concerned with the appropriateness of the Basel framework in a developing country context. For example, a banker notes that "we are transferring the framework like a software programme." ${ }^{\text {68 }}$ Another banker claims

"I do not think the framework is suitable for countries like Turkey. Developing countries are poor, so limited resources are more precious. Imposing higher levels of capital requirements do not fit local conditions... [Compliance with] Basel is not harmonised or synchronised. Turkey is forced to comply with it. In a developing country, banking can be conducted with a low level of capital. That is why it is harsh to ask developing countries to be compliant with the framework."69

\footnotetext{
${ }^{66}$ See Walter (2008).

${ }^{67}$ Interview, B5, HSBC, Istanbul, 7 March 2016.

${ }^{68}$ Interview, B3, T. Is Bank, Istanbul, 1 March 2016.

${ }^{69}$ Interview, B2, T. Is Bank, Istanbul, 1 March 2016.
} 
The emphasis on developing countries' compliance is corroborated in a statement of a group of bankers in a state-owned bank

"The country is still developing, so the standards applied in a developed country should not be the same [in a developing country]. For instance, in project finance, loans are used to finance large infrastructure projects. If we have to set aside a higher capital buffer [through the Net Stable Funding Ratio], our lending capacity declines significantly."

The bankers' concerns underline that they have a critical, sceptical stance against compliance, although they had stated earlier that they should comply given that "sanctions" in case of noncompliance can inflict upon the country, which refers to the interpretation of compliance being unfavourable to their interests. In other words, bankers may need to trade costs and benefits of compliance.

The interpretation stage reveals that compliance serves domestic actors' interests, but compliance forces do not fully eliminate concerns about compliance with Basel III as the regulatee is still worried about costs of compliance and appropriateness of the standards. Thus, it is legitimate to expect a sceptical, critical regulatee to mobilize at the domestic and/or the international levels for various aims that might include amendments on the international framework when it is brought to the domestic level for adoption or through complementary regulations that could negate the impact of the adopted framework. For example, Young argues that when the European banks were not influential in the revision of the Basel framework in line with their interests, they mobilized at the European level. ${ }^{71}$ The Capital Requirements Directive (CRD) IV had a "softer" approach than the Basel regulations due to

\footnotetext{
${ }^{70}$ Interview, B1, Ziraat Bank, Istanbul, 25 February 2016.

${ }^{71}$ Young (2014).
} 
banks lobbying at the regional level. A similar case is not observed in the Turkish case, although the banking sector still has concerns about compliance. The next stage demonstrates why the Turkish banking sector could not mobilize despite its concerns, and how the country achieved full compliance.

\section{Stage 2.2: The Determinants of Interaction, the Domestic Policy Process, and Compliance}

The domestic policy process, following the interpretation stage and crystallization of preferences and interests, is subject to a bargain between the domestic actors. During the bargain, "regulatory capacity" of regulators and the regulatee's "capture capacity" are crucial, since these capacities define the terms of interaction.

In the Turkish case, the section above demonstrated that compliance forces provided a common ground for both regulators and banks about the benefits of compliance and costs of non-compliance. However, a clash between bankers' concerns about costs of compliance and the applicability of the framework to a developing country and their preference for compliance could lead one to expect an antagonistic domestic policy process. The rest of the analysis shows that "regulatory capacity" of the regulators, as well as the policymaking structure, did not allow bankers to influence the process.

The main sources of both "regulatory capacity" and "capture capacity" are operational, analytical, and political resources. ${ }^{72}$ Political resources need analytical and operational bases to be activated and used for dominance to steer a process so that it is shaped according to the better-resourced actors' preferences. Here, operational and analytical resources involve quality human resource base, access to data and information, and analytical skills for policy

\footnotetext{
${ }^{72} \mathrm{Wu}$, Ramesh, and Howlett (2015); Wu, Howlett, and Ramesh (2018).
} 
analysis. $^{73}$ They defined the relative position of each actor in the domestic policy process in the case of Turkey's compliance with Basel III.

A former senior official of the BRSA states that "we had recognised the needs to invest in human resources and adapted the organisation according to the needs of the domestic and international economy." ${ }^{, 74}$ This refers to the BRSA's efforts in investing in human resource base by hiring more employees with postgraduate degrees following BCBS membership in 2009 (figure 2). In 2003, three years after the establishment of the BRSA, there were 323 employees, 63 out of whom had a postgraduate degree, which was 19.3 percent of the BRSA's total number of employees that year. In 2008, the BRSA had 499 employees, 20.6 percent of who had a postgraduate degree. Following membership, the number of employees with a postgraduate degree has increased from 103 in 2008 to 187 in 2015.

Figure 2: Number of Employees BRSA

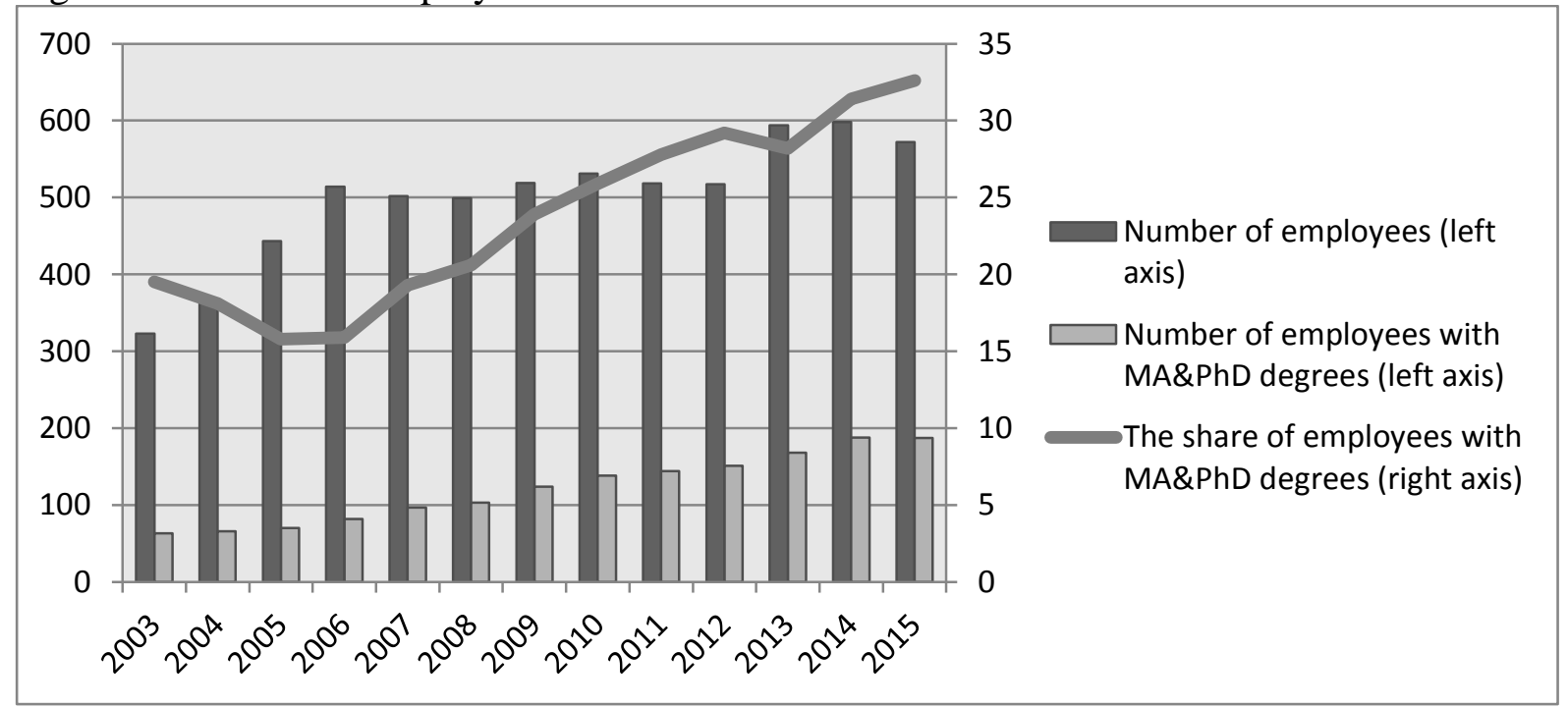

Source: Banking Regulation and Supervision Agency, Annual Reports, 2003-15.

In other words, figure 3 shows that the total number of employees increased by 54.4 percent, while those with a post-graduate degree rose by 63.4 percent between 2003 and 2008 .

\footnotetext{
${ }_{73}^{73}$ Macrae (1991); Maggetti and Gilardi (2014); Ibid.

${ }^{74}$ Interview, R1, BRSA, Istanbul, March 4, 2016.
} 
Between 2009 and 2015, the total number of employees rose by 10.2 percent, while the number of employees with a postgraduate degree increased by 50.8 percent. Finally, since 2003, the BRSA's human resource base has expanded by 77 percent, whereas, the number of employees with a postgraduate degree has risen by 196.8 percent. More than 80 percent of employees are trained in economics, finance, mathematics/statistics. ${ }^{75}$

Figure 3: Human Resource Base, BRSA, in percentages

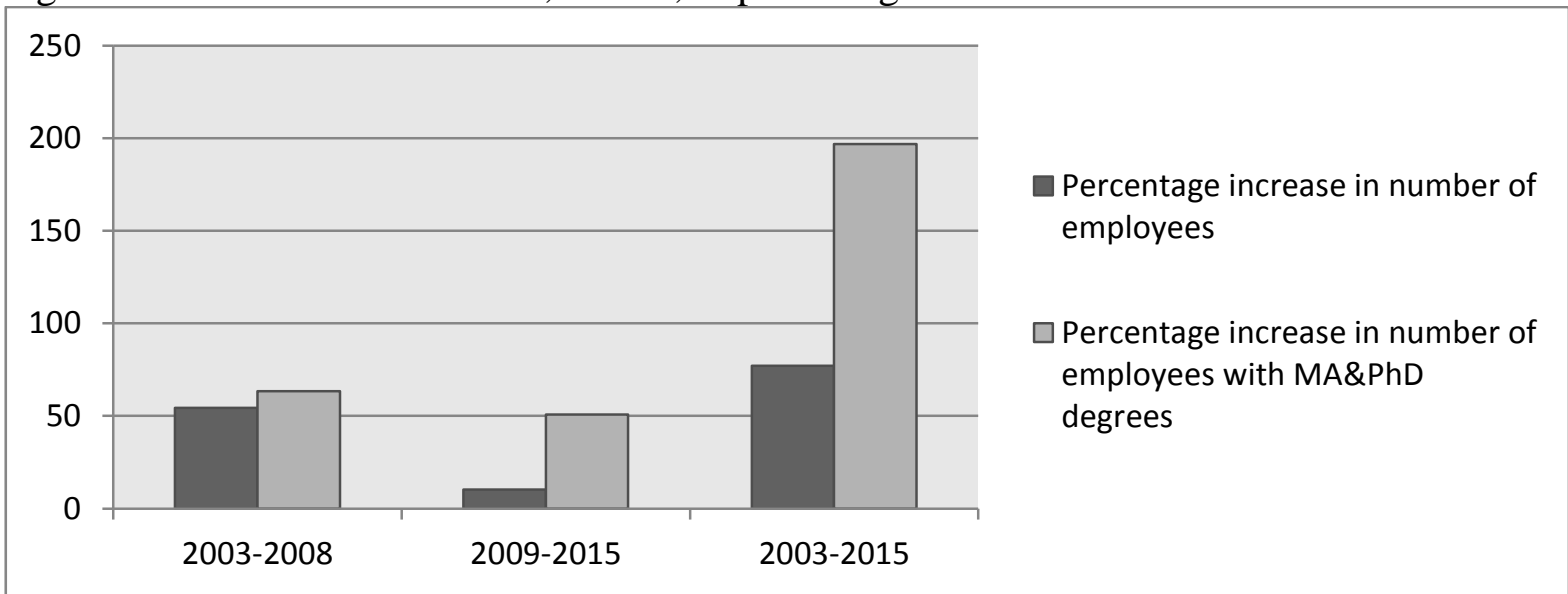

Source: Banking Regulation and Supervision Agency, Annual Reports, 2003-15.

Second, the BRSA has been investing in on-site professional training and postgraduate education. The BRSA documents that training expenses, on average, consumed 4.9 percent of annual expenses between 2009 and $2015 .^{76}$ The BRSA employees are trained in banking, auditing, risk, and macro-economy. ${ }^{77}$ The reports indicate that BRSA staff receives training by the Federal Deposit Insurance Corporation (FDIC) of the United States, the International Monetary Fund, and the Bank for International Settlements. ${ }^{78}$

In contrast, the Turkish banking sector persistently lacks access to data and skilled human resource base. For example, figure 4 indicates that the sector lacks access to data to evaluate

\footnotetext{
${ }^{75}$ BDDK $(2014 ; 2015)$.

${ }^{76}$ BDDK (2014), 136; (2015), 134.

${ }^{77}$ BDDK (2015), 132.

${ }^{78}$ BDDK (2014), 135; (2015), 133.
} 
default risk in three major circumstances, namely loss given default, exposure at default, and loss at a bank's own default.

Figure 4: Turkish Banks' Concerns for Compliance with the Basel Framework, in percentages

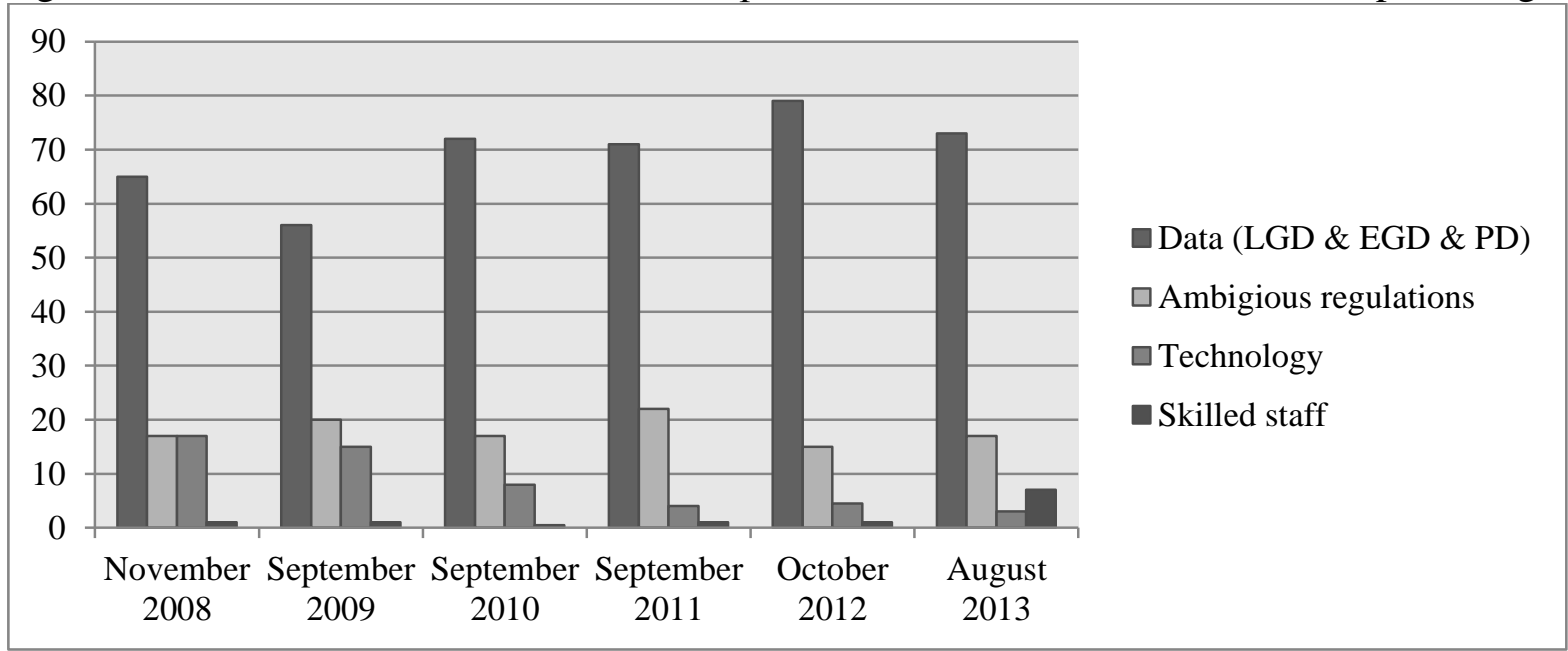

Source: Banking Regulation and Supervision Agency, http://www.bddk.org.tr/WebSitesi/turkce/Basel/Basel_II.aspx, accessed on 10 February 2016. Note: "LGD" is loss given default; "EGD" refers to exposure to default, and "PD" is the probability of default.

Since November 2008 until the last set of observations in the August 2013 survey, the BRSA had been conducting surveys. Between forty-seven and forty-five banks out of the total number of banks in the respective years responded to the surveys. The survey asked the banks to define the fundamental challenges they had been facing to implement Basel II. Sixty-five percent of the survey sample mentioned lack of access to data to evaluate default risk as the most fundamental problem for implementation in 2008. The figure reached its peak in 2012 when it rose to 79 percent. Technological capacity concerns declined from 17 percent in 2008 to 3 percent in 2013. The Turkish banking sector was concerned about ambiguities in the regulations. This varied between 17 and 22 percent. Finally, the lack of skilled human resource base had been pointed out as a marginal issue in 2008 as only 1 percent of surveyed banks identified it as a problem. By August 2013, it rose to 7 percent. 
The rise in the concern for a skilled labor force is as crucial as other dimensions the banks had reported. Even if the Turkish banking sector had access to sufficient data, processing that data requires skilled labor because the technicality and complexity of the Basel standards necessitate a high level of financial literacy to understand and implement the regulations at the firm level. A senior banker states that "not everyone [in the sector] understands what a CoCo $^{79}$ is. ${ }^{\prime 80}$ According to the statistics of the BAoT, there are 196,699 employees ${ }^{81}$ in the Turkish banking sector as of December 2016, only 13,546 of which hold a postgraduate degree. In other words, the share of employees with a postgraduate degree is 6.8 percent. $^{82}$ In December 2008, before BCBS membership, there were 171,598 bankers, 7,163 of which had a postgraduate degree, which means that only 4.1 percent of the employees had a postgraduate degree.

On the one hand, the percentage rise in the number of skilled employees is meaningful, as the banking sector seems to attract employees with a better educational background. On the other hand, concerns with the lack of skilled human resource base have become more pronounced (see figure 4). Furthermore, professional training is as important as formal education. The banking sector lacks skilled employees with qualified professional training, which could have equipped the banking sector in the politics of compliance. A senior banker notes that there are only around 200 bankers who have obtained an advanced risk management certificate (e.g., CFA, FRM, etc.). ${ }^{83}$ This shows that out of 196,699 employees, only around 200 bankers are

\footnotetext{
${ }^{79}$ Convertible contingent $(\mathrm{CoCo})$ is a debt instrument. It is convertible into an equity asset in case of default on debt. See http://lexicon.ft.com/Term?term=cocos, accessed on 18 May 2016).

${ }^{80}$ Interview, B10, Denizbank, Istanbul, 9 March 2016.

${ }^{81}$ The figures include all employees in the Turkish banking sector, including clerical/back-office personnel. This study cannot decompose the figures to find out the exact number of "technical workers" to have a much clearer picture of the total number of bankers. However, it is considered to give an idea to the reader about the current level of human resource base in the sector.

${ }^{82}$ The figures are available at https://www.tbb.org.tr/en/banks-and-banking-sector-information/statisticalreports/20, accessed on 4 September 2016.

${ }^{83}$ Interview, B8, ING, Istanbul, 16 February 2016. "CFA" refers to Certified Financial Analyst, and "FRM" is Financial Risk Manager. The CFA Institute notes that international banks are the top employers of bankers with
} 
certified risk managers. It could be said that not all bankers need to obtain risk management certificates. Yet in a banking sector of fifty-two banks, the average number of risk managers per bank is four, at best. This means that a limited number of employees with professional training oversee risk management and compliance.

The impact of the asymmetry in operational and analytical capacities gets amplified especially when the local banking sector is domestic-market oriented. A banker notes that "I would be surprised if you have met anyone during your fieldwork, who is working with a global perspective and a robust risk management orientation." ${ }^{, 84}$ Another banker notes that "when we receive a consultative document, we do not look into the details. We rather assess its methodology and coherence." ${ }^{85}$ This is corroborated by a senior official at the BRSA, who pointed out that "when we receive a document from the BCBS, we request feedback from the sector. They [the sector] are very passive, and we sometimes have to push the sector to give us feedback." $" 86$

Zingales maintains that "to detect power of corporations we need to look at output, not inputs. ${ }^{, 87}$ In the Turkish case, as the output fully resembles the framework, we can argue that the regulatee was not influential. Its "passive" participation in the domestic policy process can be argued to originate from somewhat overlapping preferences and interests for compliance. However, we have noted the regulatee's concerns regarding the suitability of the framework to the local context and future costs of compliance, which would lead us to expect its mobilization, at least, to address those costs. Yet an asymmetry in "regulatory capacity" and

\footnotetext{
advanced professional degrees such as the CFA Charter; see

https://www.cfainstitute.org/about/research/Pages/index.aspx, accessed on 11 January 2018.

${ }^{84}$ Interview, B10, Denizbank, Istanbul, 9 March 2016.

${ }^{85}$ Interview, B4, Akbank, Istanbul, 4 March 2016.

${ }^{86}$ Interview, R5, BRSA, Ankara, 20 January 2016.

${ }^{87}$ Zingales (2017), 123.
} 
"capture capacity" in the form of operational and analytical resources in addition to the domestic market orientation of the banking sector can explain part of the "story" why the outcome is full compliance.

While an asymmetry in resources and the banking sector's domestic market orientation-a business model that prioritizes serving the local market - partly explain full compliance, the final stage also is marked by additional drivers of full compliance at the domestic level. These relate to the domestic policy process and another asymmetry in a key resource: participation in international negotiations, a significant opportunity structure constituted by interdependence.

The regulatory policy process in Turkey takes place through a feedback system. The feedback system operates as follows. When the BRSA drafts a regulation, it is announced on the BRSA's website and is shared with the BAoT. The BAoT circulates the draft regulation in the banking sector. When it gets the feedback from the sector, the BAoT collates and shares it with the BRSA. The feedback system locates the BAoT as an intermediary between the banking sector and the BRSA because the BRSA does not negotiate drafts with individual banks. The BAoT negotiates with the BRSA. Surely, the BAoT is not a monolithic entity. Banks can have conflicting views on a given policy issue. The BAoT's role is to strike a balance and communicate that position with the BRSA. ${ }^{88}$

The large majority of the interviewed bankers highlight that the feedback system is not pluralistic. A restrictive policymaking process relates to the paternalistic policymaking style in Turkey. An institutionalized policymaking style, the paternalistic policymaking refers to

\footnotetext{
${ }^{88}$ Interview, B11, BAoT, Istanbul, 2 March 2016.
} 
the domination of the state in the policy process vis-à-vis non-state actors including the private sector. ${ }^{89}$ This refers to the BRSA's policy style, which is a uni-directional relationship that prevents the Turkish banking sector from engaging in the negotiations in Basel, as well as decisively in the domestic realm. For instance, bankers note that the BRSA does not ask for feedback before the officials depart for negotiations in Basel. The banking sector is mostly briefed or asked for feedback when a regulation is drafted following the transfer of the Basel framework into the domestic realm. A banker from a foreign bank notes that "I am not aware if the BRSA opened such a channel [banks consulting the BCBS individually]. If you do [consult the BCBS individually], the BRSA would tell you that you had to first consult the BRSA before directly contacting the BCBS." 90

Moreover, the BRSA is an intermediary between the BCBS and the Turkish banking sector. The paternalistic policy process and the asymmetry in operational and analytical capacities nurture another resource asymmetry: "negotiation knowledge."91 Negotiation knowledge refers to independence of regulatory agencies from their "bureaucratic master," the ministry. Regulatory agencies gain leverage (and autonomy) vis-à-vis ministries by relying on information asymmetry, as they are an intermediary between the international body and the ministry.

Applied to the domestic policy process of compliance with international (regulatory) standards, a regulatee, which does not or cannot have (direct) access to international negotiations, may not be able to mobilize not only in the international realm but also in the domestic realm. Although there might not be a perfect information asymmetry because the BCBS draft regulations are publicly available, a lack of direct access to negotiations could

\footnotetext{
${ }^{89}$ Bolukbasi and Ertugal (2018).

${ }^{90}$ Interview, B8, ING, Istanbul, 16 February 2016.

${ }^{91}$ Ruffing (2015).
} 
prevent the local banking sector from "winning at home," even if it might "lose abroad." The asymmetry in negotiation knowledge arises from the BRSA's participation in the BCBS policy process, which enables the BRSA to be informed about the regulations and their technicalities before the BRSA briefs the domestically-oriented and passive Turkish banking sector, and how they would be enforced at the domestic level. The BRSA naturally participates in the BCBS policy process. This is not (directly) accessible to the Turkish banking sector.

Thus, negotiation knowledge is crucial to the banking sector. Chalmers argues that international banks mobilize better at the international level more than domestically-oriented banks. $^{93}$ This is mainly driven by their better access to negotiations at the international level. While the literature suggests mixed results of their influence at the international level, ${ }^{94}$ international banks are better represented at the international level. Representation means that international banks can resist or more actively partake in international negotiations. With better representation at the international level, international banks acquire "negotiation knowledge," which could be used for mobilization at the domestic level even if they cannot influence the standards at the international level. In contrast, banks in smaller markets are less influential at the international level with a relatively low level of representation at the international level due mainly to lack of resources and their dominantly domestic marketoriented business model, as the Turkish case also indicates. Yet the opportunity structure transnationalization opens up in the form of cooperation with their peers so as to boost their "negotiation knowledge" can still benefit these banks. They can use such knowledge as a bargaining chip in the domestic policy process. Building on the opportunity structure at the international level, the Turkish banking sector could have boosted its "negotiation

\footnotetext{
${ }^{92}$ Young (2014).

${ }^{93}$ Chalmers (2017).

${ }^{94}$ Lall (2012); Young (2014).
} 
knowledge." However, the lack of skilled human resource base and domestic market orientation prevented the sector from engaging in such activities. Consequently, the BRSA's willingness and its top-down policymaking style as well as asymmetries in resources drove the country towards full compliance with Basel III.

\section{Conclusion}

This article examined a second mover's compliance with international regulatory standards. To this aim, it studied Turkey's compliance with Basel III. It underlined that the regulator capitalized on the institutionalized, top-down policymaking style that restricted the regulatee's access to international negotiations, and dominated the domestic policy process. While doing so, an asymmetry in resources and negotiation knowledge helped the regulator overcome the banking sector's scepticism and critical stance against compliance, which led to full compliance of Turkey with Basel III.

Besides specifying factors driving a second mover's compliance with international regulatory standards, the article casts light upon the compliance process. The article highlighted that compliance had three stages. The first stage is policy formulation and enforcement at the international level. In between the domestic policy process and that at the international level is the interpretation stage at which domestic actors crystallize their preferences regarding (non)compliance. Following that stage domestic actors' bargain determines whether or not the jurisdiction complies with the international standards.

As with any study, caveats are natural, which are opportunities for further research. Jones and Zeitz find that countries with a higher level of financial development and a higher level of 
foreign bank presence are more likely to comply with the Basel standards. ${ }^{95}$ The Basel standards are mainly devised to address regulatory gaps in developed countries with more advanced financial products and techniques. Compliance of a country with a relatively lower level of financial depth and/or the banking sector operating with simpler financial products and techniques in developed countries, such as Canada and Australia, ${ }^{96}$ or in developing countries, such as Turkey, could be a smooth process. The banking sector can adopt the regulations because compliance is less costly because regulations do not introduce substantial restrictions on a simpler business model with negligible effect on profitability and/or competitiveness. Meanwhile, regulators may comply with international "best practices" and follow the standards with which they can signal peers and market actors that they are implementing the state-of-the-art framework. In short, none of the domestic actors loses, but could simply comply with international standards.

As for foreign bank presence, a large number of foreign banks with more than a 50 percent share in total number of commercial banks (see table 1) could be said to have facilitated Turkey's compliance because parent banks can assist subsidiaries or branches in the compliance process with resources, such as know-how transfer or capital injection. Foreign bank presence in the host jurisdiction can have significance for two reasons. Firstly, parent bank know-how transfer to subsidiaries or branches can diffuse into the local banking sector. Secondly, as more banks comply, the other banks can join the effort, which might be oriented toward that end by the regulator to ensure consistency across individual banks. This study cannot report if foreign bank presence was an enabling factor in the Turkish case. This is because the fieldwork did not record such significant role as foreign bank presence facilitating the compliance process. As the analysis indicates, there was a common critical stance against

\footnotetext{
${ }^{95}$ Jones and Zeitz (2017).

${ }^{96}$ See Bakir (2019), 9.
} 
compliance with Basel III among interviewed bankers regardless of variation in the ownership structure.

Moreover, it should be noted that rather than the number of banks with distinct ownership structure, total assets, which are affected directly by (stringent) regulations, influence bank behavior. State-owned and privately-owned banks dominate the Turkish banking sector by total assets. Their approach to compliance, therefore, becomes critical because compliance is more costly for these banks. This article documents that despite the critical and sceptical stance of both domestically-owned and foreign-owned banks, Turkey achieves compliance with Basel III. Still, an intriguing area for future research relates to our limited knowledge of whether or not the ownership structure is a significant factor in explaining bank mobilization along with resources and regulations at home. ${ }^{97}$

This article shows that compliance is more likely when the distribution of costs and benefits of compliance across domestic actors favor the more capable, willing actor. This outcome could be a result of various other combinations of these factors, which deserve further examination. ${ }^{98}$ In this light and related to the analytical framework presented in this article, further research can examine why some of the new members of the BCBS, namely Saudi Arabia, South Korea, India, and Indonesia, are materially compliant in some of the pillars of Basel III, ${ }^{99}$ and whether the framework applies to these countries to explore the factors leading to partial compliance.

\footnotetext{
${ }^{97}$ See Chalmers (2017).

${ }^{98}$ See James (2016) for a recent attempt.

${ }^{99}$ See RCAP assessments, https://www.bis.org/bcbs/implementation/rcap_jurisdictional.htm, accessed on 30 January 2019.
} 
Further research can examine the stages of compliance with international regulatory standards. The article examined a second mover's compliance through the lens of a static process. However, we can conceive of dynamic and complex processes as well. For example, preferences developed at the "interpretation" stage might feed into the international level, which in turn could influence how politics of compliance take place at that level with potential implications for domestic politics of compliance or vice versa.

Finally, the sceptical and critical stance of the Turkish banking sector calls to mind whether the Basel framework is appropriate for developing countries as Claessens, Underhill, and Zhang and recently Jones and Knaack have questioned. ${ }^{100}$ On the one hand, more representation at the international level with the inclusion of developing countries in international fora may serve the less powerful to gain access to international negotiations, ${ }^{101}$ designing regulatory policies. On the other hand, taking into consideration country-specific factors could lead to a more effective, inclusive framework.

\footnotetext{
${ }^{100}$ Claessens, Underhill, and Zhang (2008); Jones and Knaack (2017).

${ }^{101}$ Grynberg and Silva (2006).
} 
Appendix 1: Interview Data

\begin{tabular}{|c|c|c|c|c|c|c|}
\hline Code / Category & Afflilation (0wnership*/Rank**) & Role & Status & Source & Date & Place \\
\hline \multicolumn{7}{|l|}{ Bankers } \\
\hline$\overline{\mathrm{Bl}}$ & Ziraat Bank (S/1) & Senior Officials & Group interview (Four officials) & Sample frame \& Referral & February 25, 2016 & Ziraat Tech Campus, Istabul \\
\hline B2 & TIs Bank (P/2) & Senior official & Individual Interview & Sample frame & March 1,2016 & Headquarters, Istanbul \\
\hline B3 & TIs Bank (P/2) & Senior oficicial & Individual Interview & Sample frame & March 1,2016 & Headquarters, Istanbul \\
\hline B4 & $\operatorname{Akbank}(\mathrm{P} / 4)$ & Senior officials & Group interview (Two officials) & Sample frame \& Referral & March 4, 2016 & Headquarters, Istanbul \\
\hline B5 & $\operatorname{HSBC}(\mathrm{F} / 13)$ & Senior official & Individual Interview & Sample frame & March 7,2016 & Headquarters, Istanbul \\
\hline B6 & Yapi Kredi Bank (P/5) & Senior officials & Group interview (Four officials) & Sample frame \& Referral & February 9, 2016 & Headquarters, Istanbul \\
\hline B7 & Fimansbank (F/8) & Senior officials & Group interview (Two officials) & Sample frame \& Referral & March8,2016 & Headquarters, Istanbul \\
\hline B8 & $\mathbb{N G}(F / 11)$ & Senior oficial & Individual Interview & Sample frame & February 16, 2016 & Headquarters, Istanbul \\
\hline B9 & $\operatorname{TEB}(\mathrm{F} / 10)$ & Senior oficial & Individual Interview & Sample frame & March 1,2016 & Headquarters, Istanbul \\
\hline B10 & Denizbank (F/9) & Senior oficial & Individual Interview & Sample frame & February 29, 2016 & Headquarters, Istanbul \\
\hline B11 & Banks' Association of Turkey & Senior officials & Group interview (Two officials) & Sample frame \& Referral & March 2,2016 & Headquarters, Istanbul \\
\hline \multicolumn{7}{|l|}{ Regulators } \\
\hline$\overline{\mathrm{Rl}}$ & BRSA & Former Senior Official & Individual Interview & Referred by R2 & March4,2016 & Meeting outside the BRSA Branch, Istanbul \\
\hline $\mathrm{R} 2$ & BRSA & Former Senior Official & Individual Interview & Referred by R4 & February 19,2016 & BRSA Branch, Istanbul \\
\hline $\mathrm{R} 3$ & BRSA & Senior Official & Individual Interview & Sample frame & January 11,2016 & BRSA Headquarters, Ankara \\
\hline R4 & BRSA & Senior Official & Individual Interview & Referred by R3 & January 11,2016 & BRSA Headquarters, Ankara \\
\hline R5 & BRSA & Senior Official & Individual Interview & Referred by R4 & January 20, 2016 & BRSA Headquarters, Ankara \\
\hline R6 & BRSA & Senior Official & Individual Interview & Referred by R4 & January 22, 2016 & BRSA Headquarters, Ankara \\
\hline $\mathrm{R} 7$ & BRSA & Senior Official & Indvividual Interview & Referred by R4 & March 29,2016 & BRSA Headquarters, Ankara \\
\hline $\mathrm{R} 8$ & BRSA & Senior Official & Individual Interview & Referred by R4 & February 11,2016 & BRSA Headquarters, Ankara \\
\hline
\end{tabular}

\section{References}

Abbott, K.W., and D. Snidal. 2000. "Hard and Soft Law in International Governance." International Organization 54 (3): 421-56.

Ayadi, R., S.B. Naceur, B. Casu, and B. Quinn. 2016. "Does Basel Compliance Matter for Bank Performance?” Journal of Financial Stability 23: 15-32.

Avgouleas, E. 2012. Governance of Financial Markets: The Law, Economics, the Politics. Cambridge, United Kingdom: Cambridge University Press.

Baccini, L., and J. Urpelainen. 2015. Cutting the Gordian Knot of Economic Reform: When and How International Institutions Help. New York: Oxford University Press.

Bach, D., and A.L. Newman. 2007. "The European Regulatory State and Global Public Policy: Micro-institutions, Macro-influence.” Journal of European Public Policy 14 (6): 827-46.

Baker, A. 2010. "Restraining Regulatory Capture? Anglo-America, Crisis Politics and Trajectories of Change in Global Financial Governance." International Affairs 86 (3): 647-63. 
Baker, A. 2013. "The Gradual Transformation? The Incremental Dynamics of Macroprudential Regulation." Regulation \& Governance 7 (4): 417-34.

Bakir, C. 2009. "Policy Entrepreneurship and Institutional Change: Multilevel Governance of Central Banking Reform.” Governance 22 (4): 571-98.

Bakir, C. 2015. "Bargaining with Multinationals: Why State Capacity Matters.” New Political Economy 20 (1): 63-84.

Bakir, C. 2019. "How Do Mega-bank Merger Policy and Regulations Contribute to Financial Stability? Evidence from Australia and Canada." Journal of Economic Policy Reform $22(1): 1-15$.

Bakir, C., and M.K. Coban. 2018. "Policy Analysis in the Central Bank.” In Policy Analysis in Turkey, edited by C. Bakir, and G. Ertan. Bristol, United Kingdom: Policy Press, 215-34.

Bakir, Caner, and Ziya Öniş. 2010. The Regulatory State and Turkish Banking Reforms in the Age of Post-Washington Consensus. Development and Change 41(1): 77-106.

Banks’ Association of Turkey. 2016a. The Banking Sector in Turkey 1960-2015, June. Istanbul.

https://www.tbb.org.tr/en/Content/Upload/Dokuman/135/The_Banking_Sector_in_Turkey_ 1960-2015.pdf.

Banks' Association of Turkey. 2016b. The Banking Sector in Turkey, 2011 December-2015 February. Istanbul. https://www.tbb.org.tr/en/Content/Upload/Dokuman/140/The_Banking_Sector_in_Turkey_ 2011-2015_December.pdf.

Banks' Association of Turkey. 2018. The Banking Sector in Turkey, 2014 March-2018 June. Istanbul. https://www.tbb.org.tr/en/research-and-publications/research/17.

BCBS. 2018. Regulatory Consistency Assessment Programme (RCAP) Handbook for Jurisdictional Assessments. Basel: Basel Committee on Banking Supervision.

Bayraktar, S. 2015. "New Regulations: Challenge or Opportunities for Turkish SMEs?" Qualitative Research in Financial Markets 7 (2): 173-90.

BDDK. 2008. Annual Report 2008. Ankara: Bankacılık Düzenleme ve Denetleme Kurumu.

BDDK. 2013. Bankacılık Sektörü Basel II Ilerleme Raporu. Ağustos [The Report on the Banking Sector's Progress on Basel II]. Ankara: Bankacılık Düzenleme ve Denetleme Kurumu.

BDDK. 2014. Ylllık Rapor 2014 [Annual Report 2014]. Ankara: Bankacılık Düzenleme ve Denetleme Kurumu. 
BDDK. 2015. Ylllık Rapor 2015 [Annual Report 2015]. Ankara: Bankacilık Düzenleme ve Denetleme Kurumu.

Bernauer, T., and V. Koubi. 2006. “On the Interconnectedness of Regulatory Policy and Markets: Lessons from Banking.” British Journal of Political Science 36 (3): 509-25.

Boot, A.W.A., and A.V. Thakor. 1993. "Self-Interested Regulation.” The American Economic Review 83 (2): 206-12.

Bolukbasi, H.T., and E. Ertugal. 2018. "Napoleonic Traditions, Majoritarianism, and Turkey's Statist Policy Style." In Policy styles and policy-making: Exploring the linkages, edited by M. Howlett and J. Tosun. London: Routledge, 351-74.

Brummer, C. 2015. Soft Law and the Global Financial System: Rule Making in the $21^{\text {st }}$ Century, second edition. New York: Cambridge University Press.

CBRT. 2013. Financial Stability Report, Volume 16, May. Ankara: Central Bank of Republic of Turkey.

Cerny, P. 2010. Rethinking World Politics: A Theory of Transnational Neopluralism. New York: Oxford University Press.

Chalmers, A.W. 2017. "When Banks Lobby: The Effects of Organizational Characteristics and Banking Regulations on International Bank Lobbying.” Business and Politics 19 (1): 107-34.

Chayes, A., and A.H. Chayes. 1993. “On Compliance.” International Organization 47 (2): 175-205.

Chayes, A., and A.H. Chayes. 1995. The New Sovereignty: Compliance with International Regulatory Agreements. Cambridge, MA: Harvard University Press.

Chey, H. 2006. “Explaining Cosmetic Compliance with International Regulatory Regimes: The Implementation of the Basle Accord in Japan, 1998-2003.” New Political Economy 11 (2): 271-89.

Chey, H. 2007. "Do Markets Enhance Convergence on International Standards? The Case of Financial Regulation.” Regulation \& Governance 1 (4): 295-311.

Claessens, S., G.R.D. Underhill, and X. Zhang. 2008. "The Political Economy of Basle II: The Costs for Poor Countries." The World Economy 31 (3): 313-44.

Demirguc-Kunt, A., L. Laeven, and R. Levine. 2011. "Regulations, Market Structure, Institutions, and the Cost of Intermediation." Journal of Money, Credit, and Banking 36 (3): 593-622.

Dolowitz, D.P., and J.C. Sharman. 2009. "Policy Transfer and Diffusion.” Policy Studies 30 (3): $269-88$. 
Drezner, D.W. 2007. All Politics is Global. Princeton, NJ: Princeton University Press.

Farrell, H., and A. Newman. 2014. "Domestic Institutions beyond the Nation-state: Charting the NIA.” World Politics 66 (2): 331-63.

Farrell, H., and A. Newman. 2016. "The New Interdependence Approach: Theoretical Development and Empirical Demonstration." Review of International Political Economy 23 (5): 713-36.

G20 (Group of Twenty). 2009. G20 Leaders Statement: The Pittsburgh Summit. Pittsburgh, PA, September 24-25.

García, K.N.A., and M. Aspinwall. 2017. "Restraining Gulliver: Institutional Reform and the Strengthening of State Capacity and Compliance." Regulation \& Governance. doi: 10.1111/rego.12181.

Goldbach, R. 2015a. Global Governance and Regulatory Failure: The Political Economy of Banking. London: Palgrave MacMillan.

Goldbach, R. 2015b. “Asymmetric Influence in Global Banking Regulation.” Review of International Political Economy 22 (6): 1087-127.

Goodhart, C. 2011. The Basel Committee on Banking Supervision: A History of Early Years 1974-1997. Cambridge, United Kingdom: Cambridge University Press.

Grynberg, R., and S. Silva. 2006. "Harmonization without Representation: Small States, the Basel Committee, and the WTO.” World Development 34 (7): 1223-36.

Hassan, M.K., O. Unsal, and H.E. Tamer. 2016. "Risk Management and Capital Adequacy in Turkish Participation and Conventional Banks: A Comparative Stress Testing." Borsa Istanbul Review 16 (2): 72-81.

Heper, M. 1992. "Strong State as a Problem for the Consolidation of Democracy Turkey and Germany Compared." Comparative Political Studies 25 (2): 169-94.

Ho, D.E. 2002. "Compliance and International Soft Law: Why Do Countries Implement the Basle Accord?" Journal of International Economic Law 5 (3): 647-88.

Holzinger, K., and C. Knill. 2005. "Causes and Conditions of Cross-National Policy Convergence.” European Journal of Public Policy 12 (5): 775-96.

Howarth, D., and L. Quaglia. 2013. "Banking on Stability: The Political Economy of New Capital Requirements in the European Union.” Journal of European Integration 35 (3): $333-46$.

IMF. 2017. Financial System Stability Assessment on Turkey. Washington, D.C.: International Monetary Fund. 
James, Sc. 2016. “The Domestic Politics of Financial Regulation: Informal Ratification Games and the EU Capital Requirements Negotiations." New Political Economy 21 (2): 187-203.

Jones, E., and A.O. Zeitz. 2017. “The Limits of Globalizing Basel Standards.” Journal of Financial Regulation 3 (1): 89-124.

Jones, E., and P. Knaack. 2017. “The Future of Global Financial Regulation.” Working Paper No.127. Oxford: The Global Economic Governance Programme.

Jongen, H. 2018. "The Authority of Peer Reviews among States in the Global Governance of Corruption." Review of International Political Economy 25 (6): 909-35.

Kapstein, E.B. 1989. "Resolving the Regulator's Dilemma: International Coordination of Banking Regulations.” International Organization 43 (2): 323-47.

Kapstein, E.B. 1992. "Between Power and Purpose: Central Bankers and the Politics of Regulatory Convergence.” International Organization 46 (1): 265-87.

Kapstein, E.B. 1994. Governing the Global Economy: International Finance and the State. Cambridge, MA: Harvard University Press.

Karacal, M., E. Can, and İ. Can. 2013. "Basel Accords: Lessons for Turkey.” Journal of Business, Economics, and Finance 2 (4): 19-32.

Knaack, P. 2017. “An Unlikely Champion of Global Finance: Why is China Exceeding International Banking Standards?” Journal of Current Chinese Affairs 46 (2): 41-73.

Kobrak, C., and M. Troege. 2015. "From Basel to Bailouts: Forty Years of International Attempts to Bolster Bank Safety." Financial History Review 22 (2): 133-56.

Külahi, E., G. Türyaki, and A. Yılmaz. 2013. “Türkiye'de Basel I, II ve III Kurallarına Uyum Süreci" [The Process of Compliance with Basel I, II and III in Turkey]. Öneri 10 (40): $185-200$.

Lall, R. 2012. "From Failure to Failure: The Politics of International Banking Regulation." Review of International Political Economy 19 (4): 609-38.

Lall, R. 2015. “Timing as a Source of Regulatory Influence: A Technical Elite Network Analysis of Global Finance." Regulation \& Governance 9 (2): 125-43.

Lavelle, K.C. 2013. Money and Banks in the American Political System. New York: Cambridge University Press.

Lavelle, K.C. 2019. U.S. Foreign Policy and the Governance of Finance. Business and Politics 21 (1):1-26.

Lindblom, C.E. 1969. The Policy-Making Process. Englewood Cliffs, NJ: Prentice-Hall. 
Lowi, T.J. 1969. The End of Liberalism: Ideology, Policy and the Crisis of Public Authority. New York: W. W. Norton.

Macrae Jr., D. 1991. "Policy Analysis and Knowledge Use." Knowledge and Policy: The International Journal of Knowledge Transfer 4 (3): 27-40.

Maggetti, M., and F. Gilardi. 2014. "Network Governance and the Domestic Adoption of Soft Rules.” Journal of European Public Policy 21 (9): 1293-310.

Marcoux, C., and J. Urpelainen. 2012. "Capacity, not Constraints: A Theory of North-South Regulatory Cooperation." The Review of International Organizations 7 (4): 399-424.

Mattli, W., and N. Woods (eds). 2009. The Politics of Global Regulation. Princeton, NJ: Princeton University Press.

Moravcsik, A. 1997. “Taking Preferences Seriously: A Liberal Theory of International Politics.” International Organization 51 (4): 513-53.

Mosley, L. 2010. "Regulating Globally, Implementing Locally: The Financial Codes and Standards Effort." Review of International Political Economy 17 (4): 724-61.

Murinde, V. (ed). 2012. Bank Regulatory Reforms in Africa. London: Palgrave MacMillan. Newman, A., and E. Posner. 2016. "Structuring Transnational Interests: The Second-Order Effects of Soft Law in the Politics of Global Finance." Review of International Political Economy 23 (5): 769-98.

Newman, A., and E. Posner. 2018. Voluntary Disruptions: International Soft Law, Finance, and Power. New York: Oxford University Press.

Oatley, T., and R. Nabors. 1998. "Redistributive Cooperation: Market Failure, Wealth Transfers, and the Basle Accord." International Organization 52 (1): 35-54.

Putnam, R.D. 1988. "Diplomacy and Domestic Politics: The Logic of Two-Level Games." International Organization 42 (3): 427-60.

Quaglia, L. 2007. “The Politics of Financial Service Regulation and Supervision Reform in the European Union.” European Journal of Political Research 46 (2): 269-90.

Quaglia, L. 2012. “The 'Old' and 'New' Politics of Financial Services Regulation in the European Union.” New Political Economy 17 (4): 515-35.

Quaglia, L. 2019. "The Politics of State Compliance with International "Soft Law” in Finance." Governance 32 (1): 45-62.

Quaglia, L., and A. Spendzharova. 2017. "Post-Crisis Reforms in Banking: Regulators at the Interface between Domestic and International Governance." Regulation \& Governance 11 (4): 422-37. 
Pasiouras, F., S. Tanna, and C. Zopounidis. 2009. “The Impact of Banking Regulations on Banks' Cost and Profit Efficiency: Cross-Country Evidence." International Review of Financial Analysis 18 (5): 294-302.

Raustiala, K. 2000. “Compliance \& Effectiveness in International Regulatory Cooperation.” Case Western Journal of International Law 32 (3): 387-440.

Rosenbluth, F., and R. Schaap. 2003. "The Domestic Politics of Banking Regulation.” International Organization 57 (2): 307-36.

Ruffing, E. 2015. “Agencies between Two Worlds: Information Asymmetry in Multilevel Policy-Making." Journal of European Public Policy 22 (8): 1109-26.

Simmons, B.A. 1993. "Why Innovate? Founding the Bank for International Settlements." World Politics 45 (3): 361-405.

Simmons, B.A. 2001. "The International Politics of Harmonization: The Case of Capital Market Regulation.” International Organization 55 (3): 589-620.

Simmons, B.A., and Z. Elkins. 2004. "The Globalization of Liberalization: Policy Diffusion in the International Political Economy." The American Political Science Review 98 (1): $171-89$.

Singer, D.A. 2007. Regulating Capital: Setting Standards for the International Financial System. Ithaca, NY: Cornell University Press.

Slaughter, Anne-Marie. 2004. A New World Order. Princeton, NJ: Princeton University Press.

Stone, D., and S. Ladi. 2015. "Global Public Policy and Transnational Administration." Public Administration 93 (4): 839-55.

Underhill, G.R. D., and X. Zhang. 2008. "Setting the Rules: Private Power, Political Underpinnings, and Legitimacy in Global Monetary and Financial Governance." International Affairs 84 (3): 535-54.

VanDeveer, S.D., and G.D. Dabelko. 2001. “It's Capacity, Stupid: International Assistance and National Implementation." Global Environmental Politics 1 (2): 18-29.

Walter, A. 2008. Governing Finance: East Asia's Adoption of International Standards. Ithaca, NY: Cornell University Press.

Woll, C. 2007. "Leading the Dance? Power and Political Resources of Business Lobbyists." Journal of Public Policy 27 (1): 57-78.

Wu, X., M. Ramesh, M. Howlett. 2015. "Policy Capacity: A Conceptual Framework for Understanding Policy Competences and Capabilities." Policy and Society 34 (3-4): 165-71. 
Wu, X., M. Howlett, and M. Ramesh. 2018. “Policy Capacity: Conceptual Framework and Essential Components." In Policy Capacity and Governance: Assessing Governmental Competences and Capabilities in Theory and Practice, edited by $\mathrm{X}$. Wu, M. Howlett, and M. Ramesh. New York: Springer Berlin Heidelberg, 1-25.

Wood, D. 2005. Governing Global Banking: The Basel Committee and the Politics of Financial Globalisation. Aldershot, Hants, England and Burlington, VT: Ashgate.

Woods, N. 2006. The Globalizers: The IMF, the World Bank, and Their Borrowers. Ithaca, NY: Cornell University Press.

Xi, C. 2016. "Why Has Basel III Become Hard Law for China? The Domestic Political Economy of International Financial Law.” In Reconceptualising Global Finance and Its Regulation, edited by R.P. Buckley, E. Avgouleas, and D.W. Arner. Cambridge, United Kingdom: Cambridge University Press, 91-104.

Young, K. 2013. “Financial Industry Groups' Adaptation to the Post-crisis Regulatory Environment: Changing Approaches to the Policy Cycle.” Regulation \& Governance 7 (4): 460-80.

Young, K. 2014. "Losing Abroad but Winning at Home: European Financial Industry Groups in Global Financial Governance since the Crisis. Journal of European Public Policy 21 (3): 367-88.

Zingales, L. 2017. “Towards a Political Theory of the Firm.” Journal of Economic Perspectives 31 (3): 113-30. 